\title{
Conservation assessment of the endemic plants from Kosovo
}

\author{
Fadil Millaku', Elez Krasniqi ${ }^{1}$, Naim Berisha ${ }^{1, *}$ \& Ferat Rexhepi ${ }^{1}$
}

Key words: Endemism, Kosovo, conservation, IUCN, endangered species.

Ključne besede: endemizem, Kosovo, ohranjanje, IUCN, ogrožene vrste.

Received: 2. 6. 2016

Revision received: 19.7 .2016

Accepted: 21. 7. 2016

\begin{abstract}
Sixteen endemic plant taxa were selected from Kosovo, according to the IUCN standards and for each taxon the risk assessment and threat category has been assigned. The taxa were compared with their previous status from fifteen years ago. From sixteen plant taxa, which were included in this work, four are Balkan endemics, whereas, eight of them are local endemics and four of the taxa are stenoendemics. Six of the taxa are grown exclusively on serpentine soils, five of them on limestone substrate, four of them in carbonate substrate, yet only one in silicate substrate. The work has been done based on the standard working methodologies of the IUCN (Guidelines for Using the IUCN Red List Categories and Criteria - Version 8.1). The most threatened plant taxa is Solenanthus krasniqii - which after its observance has only 20 mature individuals. As a result of the wild collection of the medicinal and aromatic plants, from the local population, Sideritis scardica is about to be completely go extinct. The aim of this study was to assess the state of endemics in the threats possessed to them during the previous times, present and predicting the trends for the upcoming years.
\end{abstract}

\section{Izvleček}

Na podlagi IUCN standardov smo na Kosovu izbrali šestnajst endemičnih taksonov (vrst in podvrst) in za vsakega naredili oceno tveganja in mu opredelili kategorije ogrožanja. Za posamezno vrsto smo naredili primerjavo s stanjem pred petnajstimi leti. Med izbranimi vrstami so štiri balkanski endemiti, osem je lokalnih endemitov in štirje so endemiti. Šest vrst uspeva izključno na tleh na serpentinu, pet na apnencu, štiri na karbonatni in samo ena na silikatni podlagi. Oceno smo naredili v skladu s standardno metodologijo IUCN (Guidelines for Using the IUCN Red List Categories and Criteria - Version 8.1). Najbolj ogrožena vrsta je Solenanthus krasniqii, kjer smo opazili samo še 20 odraslih osebkov. Vrsta Sideritis scardica pa je pred popolnim izumrtjem zaradi nekontroliranega nabiranja zdravilnih in aromatičnih rastlin. Namen raziskave je bil oceniti stanje endemičnih vrst, grožnje v preteklem in sedanjem času in napoved trendov ogroženosti v prihodnosti.

1 Faculty of Natural Sciences and Mathematics, University of Prishtina, St. "Nëna Terezë” n.n., 10000 Prishtina, Republic of Kosovo.

* Corresponding author. E-mail: naim.berisha@uni-pr.edu 


\section{Introduction}

The Balkan Peninsula, whom Kosovo belongs to, is known for its high diversity in plant species, and is already known as one of the 34 global Biodiversity Hotspots (Mittermeier et al. 2004). According to Turrill (1929) approximately 6750 plant species are native to the region. The presence of endemism is considerably high with $27 \%$, while with the new discoveries in the plant species, this number is increasing. Additionally, according to Stevanović (2005) and Stevanović et al. (2007), there are somewhere between 2600-2700 Balkan endemics (species and subspecies), out of whom, 300 taxa belong to the obligate endemic sperpentinophytes (Stevanović et al. 2003) and 170 Balkan endemic geophytes to the class Monocotyledones (Tan et al. 2007). The life spectrum of the endemics in Central Serbia and Kosovo dominates from the perennial hemicryptophytes and chamaephytes and has a lower proportion of annuals and geophytes, which are closer to the high-mountain spectra (Tomović et al. 2014). The Republic of Kosovo has an area of $10.908 \mathrm{~km}^{2}$ and is located in the Western part of Balkans, in SE Europe. In Kosovo, the number of the vascular plants is estimated to be somewhere between 2800 to 3000 . From the studied taxa in this study, we have estimated that four taxa are stenoendemics (a taxon is termed Stenoendemic if it is restricted to a narrow range completely within the borders of a given country or region, e.g. within the Kosovar border), eight are local endemics (a taxon is termed Local endemic if it is restricted to a narrow area of distribution that encompasis the region between two countries, e.g. Kosovo and Albania) and four taxa are Balkan endemics (a taxon is termed Balkan endemic if it is a native or restricted plant taxon to the Balkan Peninsula). Furthermore, when concerning the endemic plants, in general, different authors, in Kosovo, mention different endemic numbers; for example Rexhepi (1982) has mentioned 12 endemic plant species, while Stevanović (1996) has mentioned 15 local endemics (namely from the "Sharri" Mountains and Albanian Alps of Kosovo). Besides the endemic plant species found in alpine and subalpine belts, there are also many Balkan and local endemics to be found, in Kosovo. In the serpentines of the Mirusha region, in central Kosovo, there have been 18 endemic plant species recorded (Krasniqi et al. 2012). In Gurana serpentines (south-eastern Kosovo), where the plant community with Stipeto-Convolvuletum compacti, 21\% of the present species are considered as Balkan endemics (Millaku et al. 2011). In Kosovo's serpentines, from Tulipa genus, two species are considered as stenoendemic ones: Tulipa kosovarica (Shuka et al. 2012) and Tulipa serbica (Tatić \&
Krivošej 1997), and one local endemic species is considered as a Tulipa scardica (Bornmüller 1923 / Syn.: Tulipa gesneriana L.). Additionally, just recently in Pashtriku Mt. (Southern Kosovo) in the calcareous substrate, a new stenoendemic species, from the genus Tulipa has been discovered, which was named as Tulipa luanica Millaku \& Elezaj (Millaku \& Elezaj 2015).

The term 'endemic' has a slightly different definition, depending on the author, e.g. according to Brown \& Lomolino (1998) when the term 'endemic' is mentioned, it means that it simply does not occurs anywhere else, while in the same year Peterson \& Watson (1998) stated that we should use 'endemic' only when referring to a taxon that is restricted to a stated geographical region (either in natural or political borders). Since narrowly endemic species are threatened frequently (Lafan \& Crisp 2003) and since areas rich in endemism are more likely to be considered as rich species (Cowling et al. 2003) the endemics constitute the foremost group of conservations.

Moreover, the population of the plant species are continuously being declined and despite of some increasing efforts made on this issue, in global levels, the rate of biodiversity loss does not appear to be slowing down (Butchart et al. 2010), while the rate of extinction, at the moment, is considered to be high. If all of the species are currently deemed to be "threatened", they would become extinct in the next century, than the future extinction rates will be 10 times bigger than the recent rates (Pimmet et al. 1995).

Furthermore, in order of achieving an establishment on the National Red List plant taxa, an evaluation of the Kosovo flora needs to be initiated (Millaku et al. 2013). From the work done, the publication of the Red Book of the Vascular Flora of the Republic of Kosovo, has been achieved where 237 plant taxa are listed, out of whom 61 proved to be Critically Endangered (CR), according to the IUCN rules and criteria's (Millaku et al. 2013).

\section{Methods}

The conservation status of sixteen plant taxa (species and subspecies), out of whom eight are local endemics, four are stenoendemics and the other four are Balkan endemics, in the Republic of Kosovo (Table 1, Figure 1) the IUCN criteria and guidelines has been assessed (IUCN 2001, 2011). All of the included species are those already listed by Millaku et al. (2013) and Stevanović (1999). The IUCN criterions, regarding the threat levels, were continuously employed. Three main types of information were available for assessment: distribution, population size, and threats. For all of the assessed plant species, GPS 
Table 1: Previous status and newly proposed threat category of the 16 plant taxa being studied. Risk values are assigned to IUCN Red List categories as follows: $\mathrm{LC}$ or $\mathrm{NT}=1, \mathrm{VU}=2, \mathrm{EN}=3$ and $\mathrm{CR}=4$.

Tabela 1: Prejšnji status in novo predlagana kategorija ogroženosti za proučevanih 16 taksonov. Vrednosti tveganja so določene po IUCN rdečem seznamu: $\mathrm{LC}$ ali $\mathrm{NT}=1, \mathrm{VU}=2, \mathrm{EN}=3$ in $\mathrm{CR}=4$.

\begin{tabular}{|c|c|c|c|c|c|c|c|c|c|c|}
\hline № Species & $\begin{array}{l}\Xi \\
\stackrel{0}{0} \\
\stackrel{0}{\leftrightarrows}\end{array}$ & $\begin{array}{l}\text { Stevanović } 1999 \\
\text { Proposed category }\end{array}$ & 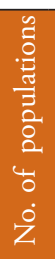 & $\frac{3}{2}$ & $\begin{array}{l}\text { Millaku et al. } 2013 \\
\text { Proposed category }\end{array}$ & 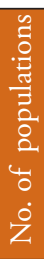 & 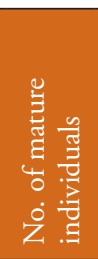 & 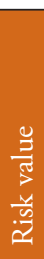 & $\begin{array}{l}\mathrm{EOO} / \\
\mathrm{km}^{2}\end{array}$ & $\begin{array}{l}\mathrm{AOO} / \\
\mathrm{km}^{2}\end{array}$ \\
\hline 1 Achillea alexandri-regis & $\mathrm{H}$ & $\mathrm{Cr} b 1+2 \mathrm{c}$ & 1 & 4 & CR - B1ab(ii,iii)+2ab(ii,iii) & 1 & $<1000$ & 4 & $<50$ & $<10$ \\
\hline 2 Aristolochia merxmuelleri & $\mathrm{G}$ & $\mathrm{Cr} \mathrm{DD}$ & 1 & 4 & $\mathbf{C R}-\mathrm{B} 1 \mathrm{ab}(\mathrm{i}, \mathrm{ii})+2 \mathrm{ab}(\mathrm{i}, \mathrm{ii})$ & 1 & $<100$ & 4 & $<50$ & 6 \\
\hline 3 Cerastium neoscardicum & $\mathrm{Ch}$ & CR B1 & 1 & 4 & CR - B1ab(i,ii,iii,iv $)+2 a b(i, i i, i i i, i v)$ & 1 & $>4000$ & 4 & $<5$ & $<1$ \\
\hline 4 Crepis bertiscea & $\mathrm{H}$ & CR B1 & 1 & 4 & $\mathbf{C R}-\mathrm{B} 2 \mathrm{ab}(\mathrm{i}, \mathrm{ii}, \mathrm{iii})$ & 2 & $<250$ & 4 & $<10$ & $<2$ \\
\hline 5 Crepis macedonica & $\mathrm{H}$ & CR B1C2ab D & 1 & 4 & CR - B1ab(i,ii,iii,iv $)+2 a b(i, i i, i i i, i v)$ & 1 & 40 & 4 & $<5$ & $<1$ \\
\hline 6 Fritillaria macedonica & G & $\mathrm{CR} \mathrm{B} 2 \mathrm{c}$ & 1 & 4 & $\mathbf{C R}-\mathrm{B} 1 \mathrm{ab}(\mathrm{i}, \mathrm{ii}, \mathrm{iii})+2 \mathrm{ab}(\mathrm{i}, \mathrm{ii}, \mathrm{iii})$ & 1 & $<80$ & 4 & $<10$ & $<5$ \\
\hline $\begin{array}{l}7 \text { Gentiana pneumonanthe } \\
\text { subsp. nopcsae }\end{array}$ & $\mathrm{H}$ & CR B2bcd & 2 & 4 & EN - B1ab(i,ii,iii,iv) +2ab(i,ii,iii,iv) & 2 & - & 3 & $<400$ & $<100$ \\
\hline 8 Linum elegans & $\mathrm{H}$ & CR DD & 1 & 4 & $\mathbf{V U}-\mathrm{D} 2$ & 2 & - & 2 & $<60$ & $<10$ \\
\hline 9 Senecio scopolii & $\mathrm{H}$ & CR Srb DD & 2 & 4 & $\mathbf{E N}-\mathrm{B} 1 \mathrm{ab}(\mathrm{i}, \mathrm{ii}, \mathrm{iv})+2 \mathrm{ab}(\mathrm{i}, \mathrm{ii}, \mathrm{iv})$ & 2 & - & 3 & $<300$ & $<100$ \\
\hline 10 Sideritis scardica & $\mathrm{Ch}$ & $\mathrm{CR}, \mathrm{B} 1+2 \mathrm{c} C 2 \mathrm{~b}$ & 1 & 4 & CR - B1ab(i,ii,iii $)+2 a b(i, i i, i i i)$ & 1 & - & 4 & $<10$ & $<5$ \\
\hline 11 Silene pusilla subsp. candavica & $\mathrm{H}$ & CR B1 & 1 & 4 & CR - B1ab(i,ii,iii,iv $)+2 a b(i, i i, i i i, i v)$ & 1 & 360 & 4 & $<50$ & $<10$ \\
\hline $\begin{array}{l}12 \text { Silene retzdorffiana } \\
\text { subsp. nikolicii }\end{array}$ & $\mathrm{H}$ & CR B2c & 1 & 4 & EN - B1ab(i,ii,iii,iv $)+2 a b(i, i i, i i i, i v)$ & 1 & 400 & 3 & $<300$ & $<100$ \\
\hline 13 Solenanthus krasniqii & $\mathrm{H}$ & $\mathrm{CR} \mathrm{B} 1+2 \mathrm{ce}$ C2ab D & 1 & 4 & CR - B1ab(iii,iv)+2ab(iii,iv) & 1 & 12 & 4 & $<1$ & $<0.5$ \\
\hline 14 Stachys serbica & $\mathrm{T}$ & EX-Srb DD & - & - & $\mathbf{C R}-\mathrm{B} 1 \mathrm{ab}(\mathrm{iii}, \mathrm{iv})+2 \mathrm{ab}(\mathrm{iii}, \mathrm{iv})$ & 1 & 300 & 4 & $<70$ & $<10$ \\
\hline $\begin{array}{l}15 \text { Tulipa gesneriana } \\
\text { (Syn. Tulipa scardica) }\end{array}$ & G & CR B1 & 1 & 4 & CR - B1ab(i,ii,iii,iv) $+2 a b(i$, ii, iii,iv $)$ & 1 & $<250$ & 4 & $<5$ & $<1$ \\
\hline 16 Tulipa serbica & G & $\mathrm{Cr} \mathrm{B} 2 \mathrm{c}$ & 1 & 4 & $\mathrm{CR}-\mathrm{B} 2 \mathrm{c}$ & 1 & - & 4 & $<8$ & $<1$ \\
\hline
\end{tabular}

Figure 1: Location of plant taxa in Kosovo - with certain symbols 1. Aristolochia merxmuelleri [+]; 2. Cerastium neoscardicum [•]; 3. Gentiana pneumonanthe L. subsp. nopcsae [\$]; 4. Linum elegans [-1]; 5. Tulipa gesneriana $[\bullet]$; 6. Tulipa serbica $[\mathbf{\Lambda}] ; 7$. Achillea alexandri-regis $[$ ]; 8. Crepis bertiscea $[\mathbf{4}]$; 9. Crepis macedonica $[\Theta]$; 10. Fritillaria macedonica [0]; 11. Senecio scopolii [:安]; 12. Sideritis scardica $[\mathbf{\square}] ; 13$. Silene retzorffiana

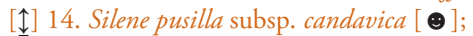
15. Solenanthus krasniqii [§]; 16. Stachys serbica $[0]$.

Slika 1: Lokacije rastlinskih taksonov na Kosovu - za simbole glej zgoraj.

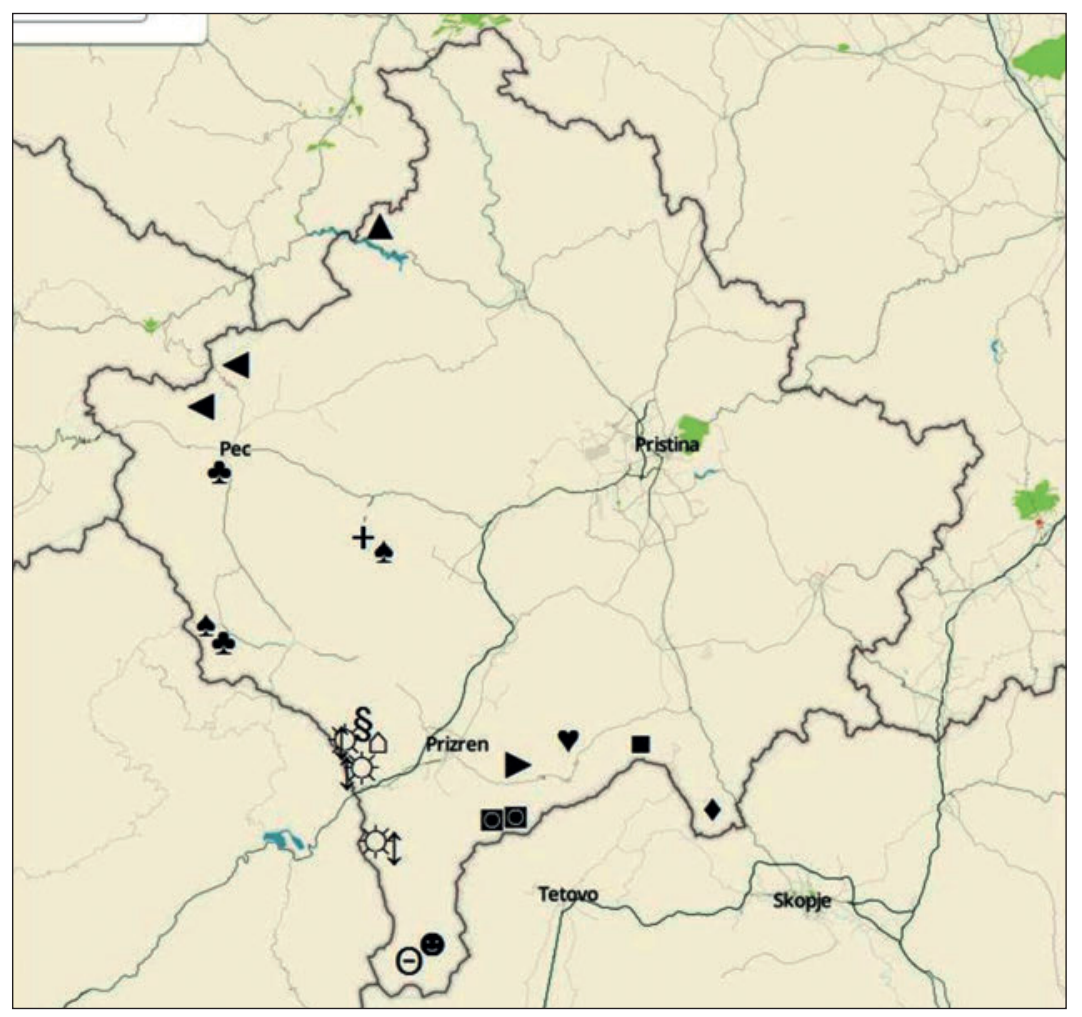


Table 2: Quantity and quality trends, main factors contributing to past degradation and habitat type of studied taxa. Tabela 2: Trendi spreminjanja (kvalitativni in kvantitativni), glavni dejavniki pretekle degradacije in habitatni tip preučevanih taksonov.

\begin{tabular}{|c|c|c|c|c|c|c|}
\hline Species & $\begin{array}{l}\text { Current } \\
\text { trend in } \\
\text { habitat } \\
\text { quantity }\end{array}$ & $\begin{array}{l}\text { Present past } \\
\text { trend in quantity } \\
\text { (over the past } 15 \\
\text { years)- \% area }\end{array}$ & $\begin{array}{l}\text { Type of } \\
\text { degradation } \\
\text { in Quality } \\
\text { indicators }\end{array}$ & $\begin{array}{l}\text { Current } \\
\text { trend in } \\
\text { habitat } \\
\text { quality }\end{array}$ & $\begin{array}{l}\text { Main factors } \\
\text { contributing to past } \\
\text { loss / degradation }\end{array}$ & $\begin{array}{l}\text { Habitat } \\
92 / 43 \text { ECE }\end{array}$ \\
\hline Achillea alexandri-regis & Decreasing & $1 \%$ decrease & Abiotic, biotic & Decreasing & $\begin{array}{l}\text { Species succession } \\
\text { and Fire }\end{array}$ & $\begin{array}{l}6170 \text { Alpine and subalpine } \\
\text { calcareous grasslands F } 2.4 \text { Subalpine } \\
\text { Pinus mugo scrub }\end{array}$ \\
\hline Aristolochia merxmuelleri & Decreasing & $2 \%$ decrease & Abiotic, biotic & Decreasing & Human activities & $\begin{array}{l}\text { 91H0 Pannonian woods with } \\
\text { Quercus pubescens }\end{array}$ \\
\hline Cerastium neoscardicum & Decreasing & $3 \%$ decrease & Abiotic, biotic & Decreasing & $\begin{array}{l}\text { Species composition } \\
\text { change (succession), fire }\end{array}$ & $\begin{array}{l}4070 \text { Bushes with Pinus mugo } \\
\text { serpentinicum }\end{array}$ \\
\hline Crepis bertiscea & Decreasing & $1 \%$ decrease & Abiotic, biotic & Decreasing & $\begin{array}{l}\text { Climatic changes and } \\
\text { succession processes }\end{array}$ & $\begin{array}{l}8210 \text { Calcareous rocky slopes with } \\
\text { chasmophytic vegetation }\end{array}$ \\
\hline Crepis macedonica & Decreasing & $3 \%$ decrease & Abiotic, biotic & Decreasing & Human activities & $\begin{array}{l}8210 \text { Calcareous rocky slopes with } \\
\text { chasmophytic vegetation }\end{array}$ \\
\hline Fritillaria macedonica & Decreasing & $3 \%$ decrease & Biotic & Decreasing & $\begin{array}{l}\text { Species composition } \\
\text { change (succession) }\end{array}$ & $\begin{array}{l}6150 \text { Siliceous alpine and boreal } \\
\text { grasslands }\end{array}$ \\
\hline $\begin{array}{l}\text { Gentiana pneumonanthe } \\
\text { subsp. nopcsae }\end{array}$ & Decreasing & $3 \%$ decrease & Abiotic, & Decreasing & $\begin{array}{l}\text { Change of water } \\
\text { regime }\end{array}$ & $\begin{array}{l}6510 \text { Lowland hay meadows } \\
\text { (Alopecurus pratensis, Sanguisorba } \\
\text { officinalis) }\end{array}$ \\
\hline Linum elegans & Decreasing & $1 \%$ decrease & Biotic & Decreasing & Human activities & $\begin{array}{l}91 \mathrm{H} 0 * \text { Pannonian woods with } \\
\text { Quercus pubescens }\end{array}$ \\
\hline Senecio scopolii & Decreasing & $1 \%$ decrease & Biotic & Stable & Human activities & $\begin{array}{l}6170 \text { Alpine and subalpine } \\
\text { calcareous grasslands }\end{array}$ \\
\hline Sideritisscardica & Decreasing & $3 \%$ decrease & Abiotic, biotic & Decreasing & Human activities & $\begin{array}{l}8210 \text { Calcareous rocky slopes with } \\
\text { chasmophytic vegetation }\end{array}$ \\
\hline $\begin{array}{l}\text { Silene pusilla subsp. } \\
\text { candavica }\end{array}$ & Decreasing & $1 \%$ decrease & Abiotic, biotic & Decreasing & Human activities & $\begin{array}{l}8210 \text { Calcareous rocky slopes with } \\
\text { chasmophytic vegetation }\end{array}$ \\
\hline $\begin{array}{l}\begin{array}{l}\text { Silene retzorffiana subsp. } \\
\text { nicolicii }\end{array} \\
\end{array}$ & Decreasing & $1 \%$ decrease & Abiotic, biotic & Decreasing & Human activities & $\begin{array}{l}8210 \text { Calcareous rocky slopes with } \\
\text { chasmophytic vegetation }\end{array}$ \\
\hline Solenanthus krasniqii & Decreasing & $10 \%$ decrease & Abiotic, biotic & Decreasing & $\begin{array}{l}\text { Human activities, } \\
\text { invasion by alien } \\
\text { species and Fire }\end{array}$ & 6520 Mountain hay meadows \\
\hline Stachys serbica & Decreasing & $30 \%$ decrease & Abiotic, biotic & Decreasing & Human activities & $\begin{array}{l}\text { 91H0 Pannonian woods } \\
\text { withQuercus pubescens }\end{array}$ \\
\hline $\begin{array}{l}\text { Tulipa gesneriana } \\
\text { (Syn.:Tulipa scardica) }\end{array}$ & Decreasing & $3 \%$ decrease & Abiotic, biotic & Decreasing & Human activities & $\begin{array}{l}\text { 91H0 Pannonian woods } \\
\text { withQuercus pubescens }\end{array}$ \\
\hline Tulipa serbica & Stable & $0.5 \%$ decrease & Biotic & Stable & Human activities & $\begin{array}{l}\text { 91H0 Pannonian woods with } \\
\text { Quercus pubescens }\end{array}$ \\
\hline
\end{tabular}

coordinates were recorded, where it was possible that all mature individuals were counted, the main threats have been posed to the plant species, alongside with the Area of Occupancy (AOO), habitat type, accompanying species, geological-pedological composition, altitude, inclination, aspect, as well as, habitat degradation scale (Table 2). The Extent of Occurrence (EOO) has been measured by using the UTM system. The map pinpointing has been realized based on the coordinates taken from the localities of the distributed species. The scientific plant names have been processed, according to The Plant List (working list of all plant species), Euro+Med PlantBase (2006) and Flora
Europea (Tutin et al. 1964-1993). The species that have not been included in the abovementioned literature (like: Gentiana pneumonanthe subsp. nopscae T. Wraber, Silene retzdorffiana subsp. nikolici A. Seliger \& Wraber, Solenanthus krasniqii Wraber as well as Tulipa serbica Tatić \& Krivošej) are named after other relevant literature, such as: Flora of Albania (I-IV), Flora of Bulgaria (I-XI), Flora of Serbia (I-X), Flora of Macedonia (I-VI), etc. The analysis, which has been conducted by using the program RAMAS Red List Professional (Akçakaya 2000), with a special importance has given the following data: species taxonomy, generation length, geographical distribution, 
data on population (number of mature individuals), Extent of Occurrence (EOO) and Area of Occupancy (AOO) in $\mathrm{km}^{2}$, number of populations/subpopulations, number of locations, main risks, length of generation, number of mature individuals, size of population and bigger subpopulation (expressed in number of mature individuals), etc. From the IUCN criteria's used to evaluate the taxa belongings to a certain threat category, the $\mathrm{B}$ criterion was the most common one used [Geographic range of occurrence (B1 - Extent of Occurrence) or the Occupancy (B2 - Area of Occupancy)] for this study (IUCN Red List Categories and Criteris 2001b). We relied more on the $\mathrm{B}$ criterion, since if we would have categorized the taxa based on the number of individuals, some taxa that have had a large number of population, hence a narrow distribution, such as the Cerastium neoscardicum, would have been categorized as CR (Critically endangered).

\section{Study area}

The land composition in Kosovo is mainly made out of mountainous regions that were analyzed thorought, always considering the vegetation form and known endemic patterns. Kosovo's landscape has experienced a considerable change during this time; particularly during the last decades because of the traditional economy, agriculture, deforestation, and human settlement expansion, which has given space to permanent threat, tension and shrinkage on natural habitats.

\section{Distribution data}

All of the data, including the taxon distribution, situation of populations and subpopulations, habitat types, and other relevant data have been obtained in the field surveys, and were updated by the bibliographical references, such as: Blečić et al. (1969), Blečić \& Krasniqi (1971), Krasniqi (1972, 1987), Rexhepi (1979, 1982, 1984, 1994, 1997, 2000), Mayer \& Greuter (1985), Niketić (1994), Stevanović (1999), Millaku (1999, 2001), Rexhepi \& Krasniqi (2004), Millaku et al. (2008), Petrova $\&$ Vladimirov (2010), Krasniqi et al. (2012), etc.

The field surveys have been conducted during 20112015, starting from the early spring until late summer, in order of investigating the local species, which have been reported in the historical floristic bibliography in the area. Checking the data presence species, completing the distribution information, counting mature individuals (where it was possible), detecting typical habitats of different taxa, and identifying threats and pressures have been the most important issues that we have focused on, during the field study. The geographical coordinates of each of the individual taxa have been recorded, by using a global positioning system, to an accuracy of $\pm 10 \mathrm{~m}$. The distributed information was used to compute the Extent of Occurrence and Area of Occupancy for each species, according to the IUCN guidelines in applying the $\mathrm{B}$ criterion (IUCN 2011). The Extent of Occurrence was obtained by delimiting a polygon that encompassed all of the known localities of a taxon. Overlaying a $4 \mathrm{~km}^{2}$ Universal Transverse Mercator (UTM) grid on the maps and summing the area in which each of the species have been located, by calculating the Area of Occupancy. Because of the narrow distributions of species and the details on spatial information, which are available in the Area of Occupancy, by using a grid of $1 \mathrm{~km}^{2}$ has been calculated. A $1 \mathrm{~km}^{2}$ grid can be used for assessment when high precision data are available (IUCN 2011). The Extent of Occurrence was often lower than the Area of Occupancy for narrow distributed species. In such cases, the Extent of Occurrence will be equal to the Area of Occupancy (IUCN 2011).

\section{Population size}

The estimation of the population size for applying the $\mathrm{C}$ and $\mathrm{D}$ criteria has been done by sampling or counting all of the mature individuals. The individuals have been counted where the population has a well confined and comprised individual. The population with unattainable counting has been sampled in all cases. This was conducted in the height of time vegetation, in each of the habitat types. The habitats, which have been identified during the field study, have been based on the existing literature source (European Commission 2013). For the estimation of the number of individuals, the following formula has been used:

$N_{s}=\sum_{i=1}^{\mathrm{n}}\left(\frac{\mathrm{u}_{\mathrm{i}}}{25} \mathrm{~S}_{\mathrm{i}}\right)$

Where: Ns is the individual species number, $\boldsymbol{\mu} \boldsymbol{i}$ is the individual mean number in habitat $\mathbf{i}, \boldsymbol{S i}$ is the total area of the habitat $\mathbf{i}$; and $\boldsymbol{\mu} \mathbf{i} / \mathbf{2 5}$ is the density per $\mathrm{m}^{2}$ (Guidi 2010).

\section{Locations}

According to the IUCN criteria (IUCN 2012), the location number and distribution of the population, have 
been defined. The IUCN (2011) guidelines define location as 'a geographically or ecologically distinct area in which a single event can rapidly affect all individuals of the taxon', which has been followed throughout the field study.

\section{Risk value}

The synthetic risk-value index for each of the taxon has been defined, while considering the increase in the risk of extinction and assigning numerical values to the IUCN categories, as follows: Near Threatened (1), Vulnerable (2), Endangered (3) and Critically Endangered (4). The total risk value is the sum of all of the risk values of the taxa, which have been studied.

\section{Results}

The distribution map for studied the taxa, based on the UTM $10 \mathrm{~km}^{2}$ grid are presented in Figure 1 - alongside with pictures of species (Figures 4 to 18). From sixteen of the evaluated taxa, one has been categorized as Vulnerable, three as Endangered, and twelve as Critically Endangered ones. We have identified two main group of threats for these endemic plant taxa, the one being human induced activities (Code 1, IUCN 2012) and the other being the limited area of distribution (Code 9, IUCN 2012). The internal factors (9.1 and 9.5 - coding for Limited dispersal and Low densities) are threats to the sixteen evaluated taxa. The group of threats belonging to the human disturbance (code 10), Fire (10.5) affects and continuously posses threats to 10 out of 16 evaluated taxa. While the group of threats belongs to Human induced habitat loss and degradation (code 1), cultural/scientific/leisure activities pose a threat to 8 out of 16 evaluated taxa, livestock (code 1.1.4) pose a threat to 6 out of 16 evaluated taxa. Whereas from the Natural disasters group (code 7), avalanches and landslides pose a threat to 3 of the taxa (Crepis macedonica Kitanov, Sideritis scardica Griseb. and Solenanthus krasniqii Wraber), and lastly, from the human induced habitat group loss, the Mining (1.3.1) pose a minor threat, by affecting Aristolochia merxmuelleri Greuter \& E. Mayer and Tulipa gesneriana L. subsp. scardica Bornm. (Table 2). It has been concluded that during a fifteen years period (19992015), the number of mature individuals of Sideritis scardica population (Figure 2), which is found in the eastern side of Luboten is being continuously reduced as a result that is being collected as a medicinal herb from the local people. The number of the mature individuals

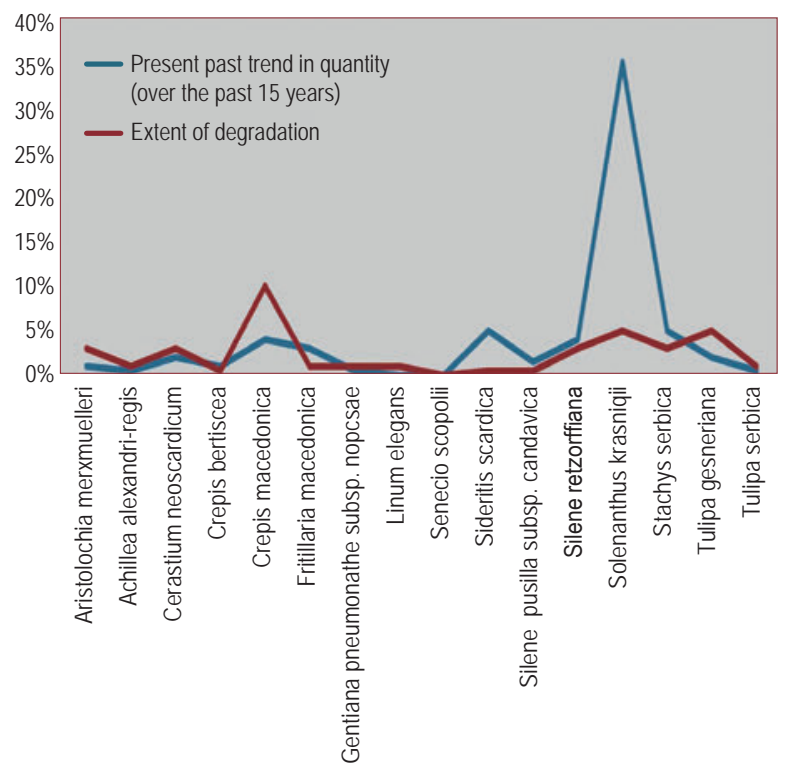

Figure 2: Extent of degradation in each taxa population (in the past 15 years and at the present) expressed in \%.

Slika 2: Obseg degradacije populacij posameznih taksonov (v zadnjih 15 letih in danes) v odstotkih.

of Crepis macedonica has been reduced, as a result of the ski-lift being built on the habitat species and the collection of botanists, by including tourists. Six of the taxa are grown in the oak zone - alliance Quercion frainetto, nine of the taxa are to be found in subalpine and alpine belts, while interestingly Stachys serbica Pancic grow from the mountainous up to the subalpine zone. Additionally, six of the taxa are typical serpentinophyte ones (Aristolochia merxmuelleri, Cerastium neoscardicum Niketić, Gentiana pneumonanthe L. subsp. nopcsae Wraber, Linum elegans Spruner ex. Boiss., Tulipa gesneriana L. subsp. scardica, Tulipa serbica Tatić \& Krivošej), nine of the taxa are found exclusively on limestone substrate (Achillea alexandri-regis Bornm. \& Rudsky, Crepis bertiscea Jáv., Crepis macedonica, Senecio scopolii Hoppe \& Hornsch., Sideritis scardica, Silene retzdorffiana (K. Malý) H. Neumayer, Silene pusilla subsp. candavica (H. Neumayer) Greuter \& Burdet, Solenanthus krasniqii and Stachys serbica) and only one taxon is found on silicate substrate (Fritillaria macedonica Bornm.). Hemicryptophytes dominates the life form groups (Figure 3 - with eight taxa), followed by Geophytes (five taxa), Chamaephytes (two taxa) and Therophytes (one taxon). From 1999 until 2015, the number of mature individuals has been reduced considerably within the population, as a result of fire, up to the following taxa: Cerastium neoscardicum, Gentiana pneumonanthe subsp. nopcsae, Linum elegans, Crepis bertiscea, Solenanthus krasniqii and Tulipa gesneriana subsp. scardica. 


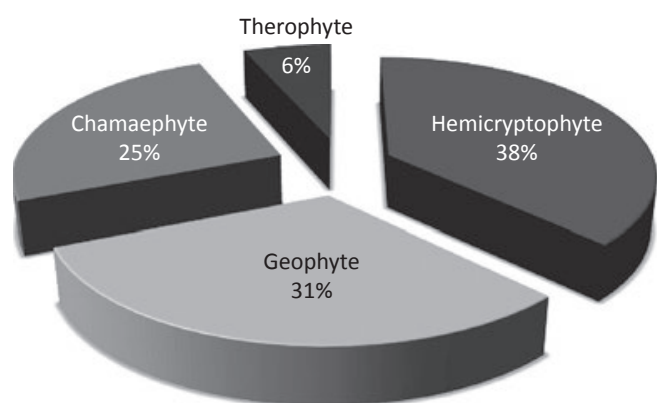

Figure 3: Life forms of studied endemic taxa.

Slika 3: Življenske oblike preučevanih endemičnih taksonov.

\section{Discussion}

From the sixteen evaluated endemic taxa, twelve are critically endangered, three are endangered, and one is vulnerable. As a result of the changed habitat management, many plant species are vulnerable to threats (Wilcove et al. 1998). Twelve plant taxa are categorized as critically endangered; the main threats to these taxa are limited distribution, low number of mature individuals, and low densities. What is important to be noted here is the categorization of the species Stachys serbica as critically endangered ones (CR), while the same species, according to Stevanović (1999) - indicating the population of the species, in Kosovo, where the species are only to be found, have gone completely extinct. The species have been found in subalpine zone, in Pashtrik (south-western Kosovo), but the number of individual mature species was too low. According to Stevanović (1999), taxa Gentiana pneumonanthe subsp. nopscae and Senecio scopolii are categorized as critically endangered ones for Serbia (in their publication, which included Kosovo), while enough information has been gathered regarding these two endemic plant species, indicating that they each have two present populations (in western Kosovo), and basing it on the B1 and B2 criterions of the IUCN, the species can only be Endangered and not Critically endangered, therefore the EN category applies to both of them (Millaku et al. 2013). Additionally, according to the EOO and AOO (respectively B1 and B2 IUCN criterions), the Linum elegans, a species that grows exclusively in the serpentine soils, have been categorized as Vulnerable, particularly because the species have three stable populations and one of them (Bokat $\mathrm{e}$ Morines, western Kosovo) has a wide distribution area and a large number of mature individuals. The same threat category has been given to the species in Bulgaria (Petrova \& Vladimirov 2009), while Stevanović (1999) categorizes $L$. elegans as critically endangered species (CR).

Since the establishment of the 'Sharri' National Park (in 1986 and its extension in 2012) and 'Bjeshkët e Nemuna' (the Albanian Alps of Kosovo) National Park (in 2012), several actions have been taken to counteract the loss of biodiversity, mainly by stopping illegal wood logging and cutting, educating young people about the importance of nature conservation and biodiversity, whereas, too little about the habitat conservation. Anyhow, as most of the threats are anthropogenic, in order of achieving more sustainable solutions, a systematic and interdisciplinary approach on biodiversity conservation has been required (Delanoë et al. 1996, Tisdell 2014). For all of the sixteen taxa that have been studied and analysed, and in particular for the twelve of them that are critically endangered (CR), ex situ and in situ conservation programmes need to be combined appropriately (Smith et al. 2010) and also the reintroduction of the projects is highly recommended (Ardestani et al. 2015, Volis 2016).

When the given limited resources of species conservation efforts and biodiversity conservation policies and campaigns, we recommend an integrated approach towards the conservation of the endemic and endangered flora of Kosovo, by combining all of the IUCN criteria with other non-IUCN criteria (Gauthier et al. 2010, Bacchetta et al. 2012), and therefore setting a list of priorities and action steps. The current study may be seen as one of the first attempts in assessing the needed priorities among the species for the inclusion of ex situ and in situ conservation programmes (Gauthier et al. 2010) in the Republic of Kosovo. From the local endemics, the most endangered ones are the following taxa: Crepis macedonica, Fritillaria macedonica, Sideritis scardica and Stachys serbica, while from the stenoendemic species, taxon Solenanthus krasniqii has only $12-15$ mature individuals. According to Stevanović (1999) species Solenanthus krasniqii had 20 mature individuals, as a result of human induced fires, while sixteen years later, the number of species counts only as 12 mature individuals (Millaku et al. 2013), so its population has been reduced by $35 \%$ in less than 15 years (Figure 2). The risk value has remained the same, as proposed by Stevanović (1999) for twelve taxa, while for four taxa it has been changed (Gentiana pneumonanthe subsp. nopcsae from 4 to 3, Linum elegans from 4 to 2, Senecio scopolii from 4 to 3 and Silene retzorffiana from 4 to 3 ).

\section{Conclusions}

The area of nature conservation in the Republic of Kosovo is regulated by the Law on Environmental Protection (LAW No. 03/L-025), other legal acts, and by laws that directly or indirectly relate to nature and natural resources. So far, 76 natural assets have been legally protected: $2 \mathrm{Na}-$ tional Parks, 11 Nature Reserves, 2 Regional Parks, and 59 Natural Monuments - which encompass $12 \%$ of the 
country area. The absence of recent data, regarding the endemic plants from the Republic of Kosovo, is one of the main reasons as to why the plants are ranked so low in the IUCN Red List of Threatened Plants (Walter \& Gillett 1997), which contain only 26 of the taxa, while the European Red List of Vascular Plants (Bilz et al. 2011) contain only 14 of the taxa. From the 4 local endemic taxa included in the study, only Crepis bertiscea is included in the World Data Book of Plants, while only Crepis macedonica is included in the European Red List of Vascular Plants (Bilz et al. 2011). Starting from steno endemic taxa that fall to Critically Endangered threat categories, the Solenanthus krasniqii is the most endangered one with $<20$ mature individuals, and species Achillea alexandri-regis $<1000$ mature individuals. Starting from the local endemic taxa, the most endangered one is Fritillaria macedonica with $<80$ mature individuals, Crepis bertiscea $<250$ and Tulipa gesneriana subsp. scardica $<250$ mature individuals. Starting from mining and related activities of habitat degradation (human induced), the taxa Tulipa gesneriana subsp. scardica and Aristolochia merxmuelleri are the most affected ones. The areas with many endemic taxa that are not currently sufficiently protected, should have a high priority on conservation (e.g. Pashtriku Mt., Mokna, serpentines terrains of Gurana, Morina, Deva and Ibar valley in the Northern Kosovo). From the taxa that have been studied, nine are to be found in Alpine and sub-Alpine belt, belonging to the two National Parks ('Sharri' National Park and 'Bjeshkët e Nemuna' National Park), while seven taxa are to be found in the hilly areas that are out of the protected zones. Six of the taxa are typically serpentinophyte ones, nine are to be found in calcareous substrate and only Fritillaria macedonica is found in silicate substrate.

\section{References}

Akçakaya, H. R., Ferson, S., Burgman, M.A., Keith, D.A., Mace, G.M. and Todd, C.R. 2000: Making consistent IUCN classifications under uncertainty. Conservation Biology 14: 1001-1013.

Ardestani, E.G., Tarkesh, M., Bassiri, M. \& Vahabi, M.R. 2015: Potential habitat modelling for reintroduction of three native plant species in central Iran. Journal of arid land 7(3): 381-390.

Bacchetta, G., Farris, E. \& Pontecorvo, C. 2012: A new method to set conservation priorities in biodiversity hotspots. Plant Biosystems 146: 638-648.

Bilz, M., Kell, S.P., Maxted, N. \& Lansdown, R.V. 2011: European Red List of Vascular Plants. Luxembourg: Publications Office of the European Union, 87 pp.

Blečić, V. \& Krasniqi, F. 1971: Endemic plant community of Forsythia and Milkworts (Polygalo-Forsythietum europaeae Blečić i Krasniqi) in South-Western Serbia. (Zajednica endemičnog sibljaka forzicije i krstusca (Polygalo-Forsythietum europaeae Blečić et Krasniqi) u jugozapadnoj Srbiji.) Glasnik Republičkog Zavoda za Zaštitu Prirode Prirodnjačkog Muzeja Titograd 4: 35-40.
Blečić, V., Tatić, B. \& Krasniqi, F. 1969: Three endemic plant communities in serpentines of Serbia. (Tri endemicne zajednice na serpentinskoj podlozi u Srbiji). Acta Botanica Croatica 28: 43-47.

Bornmüller, J. 1923: Über eine neue Tulpe der Flora Mazedoniens. Feddes Repertorium 19: 199-200.

Brown, J.H. \& Lomolino, M.V. 1998: Biogeography, 2nd edn. Sinauer Associates. Inc. Publishers, Sunderland, MA. 43 pp.

Butchart, S.H.M., Walpole, M., Collen, B., van Strien, A., Scharlemann, J.P.W., Almond, R.E.A., Baillie, J.E.M., Bomhard, B., Brown, C., Bruno, J., Carpenter, K.E., Carr, G.M., Chanson, J., Chenery, A.M., Csirke, J., Davidson, N.C., Dentener, F., Foster, M., Galli, A., Galloway, J.G., Genovesi, P., Gregory, R.D., Hockings, M., Kapos, V., Lamarque, J.F., Leverington, F., Loh, J., McGeoch, M.A., McRae, L., Minasyan, A., Morcillo, M.H., Oldfield, T.E.E., Pauly, D., Quader, S., Revenga, C., Sauer, J.R., Skolnik, B., Spear, D., Stanwell-Smith, D., Stuart, S.N., Symes, A., Tierney, M., Tyrrell, T.D., Vié, J.C., Watson, R. 2010: Global biodiversity: indicators of recent declines. Science 328: 1164-1168.

Cowling, R.M., Pressey, R.L., Rouget, M. \& Lombard, A.T. 2003: A conservation plan for a global biodiversity hotspot - the Cape Floristic Region, South Africa. Biological Conservation 112: 191-216.

Delanoë, O., D E Montmollin, B. \& Olivier, L. 1996: Conservation of Mediterranean Island Plants. 1. Strategy for Action. IUCN, Gland, Switzerland. $61 \mathrm{pp}$.

Euro+Med 2006: Euro+Med PlantBase - the information resource for Euro-Mediterranean plant diversity. Published on the Internet http:// ww2.bgbm.org/EuroPlusMed/ [accessed 10th of May 2015].

European Commission 2013: Natura 2000. Interpretation Manual of European Union Habitats. Nature ENVB. 3. 105-134 pp.

Gauthier, P., Debussche, M. \& Thompson, J.D. 2010: Regional priority setting for rare species based on a method combining three criteria. Biological Conservation 143: 1501-1509.

Guidi, T. 2010: Le piante endemiche dell'Arcipelago Toscano. Valutazione della vulnerabilità. $\mathrm{PhD}$ thesis. Scuola di Dottorato 'Ubaldo Montelatici', Dottorato in Biosistematica vegetale, ciclo XXI, Università degli Studi di Firenze. 39 pp.

IUCN 2001: IUCN Red List Categories. Version 3.1. IUCN Species Survival Commission Re-introduction Specialist Group, World Conservation Union, Gland, Switzerland, and Cambridge, UK.

IUCN 2011: Guidelines for Using the IUCN Red List Categories and Criteria: Version 9. IUCN-SSC, Biodiversity Sub-committee, Gland, Switzerland.

IUCN 2012: IUCN-CMP Unified Classification of Direct Threats. Version 3.1. Http://www.iucnredlist.org/documents/June_2012_ Guidance_Threats_Classification_Scheme.pdf [accessed 10 February 2016].

Krasniqi, E., Millaku, F. \& Rexhepi, F. 2012: Some endemic species on the flora and vegetation of Mirusha region and their condition by IUCN. IJEES 2(3): 231-236.

Krasniqi, F. 1972: Forest vegetation of mountain regions of Kosovo. (Šumska vegetacija brdskog regiona Kosova). Zajednica Naučnih Ustanova Kosova. Studije. Knj. 27. Prishtina. 37 pp.

Krasniqi, F. 1987: Endemics in flora of Kosovo and the probelms of their protection in SAP Kosovo (Endemi u flori SAP Kosovo i problemi njihove zaštite). ANU B i H. Posebna Izdanja. Knj. 14: 119-124. Sarajevo.

Laffan, S.W. \& Crisp, M.D. 2003: Assessing endemism at multiple spatial scales, with an example from the Australian vascular flora. Journal of Biogeography 30: 511-520. 
Law no. 03/L-025 on Environmental Protection. Official Gazzete of the Republic of Kosovo. 50/2009.

Mayer, E. \& Greuter, W. 1985: Aristolochia merxmuelleri, eine neue serpentin-Endemit aus Sudwest-Serbien. Botanische Jahrbücher für Systematik, Pflanzengeschichte und Pflanzengeographie 107(1-4): 321-327.

Millaku, F. 1999: Subalpine and alpine flora of the Albanian Alps of Kosovo. PhD Thesis. FNSM - University of Prishtina, Kosovo. (Flora subalpike dhe alpike e Alpeve Shqiptare (Kosovë). Disertacion i doktoratës. UP-FSHMN. Prishtinë.) 93 pp.

Millaku, F. 2001: Endemic plants in flora of Albanian Alps. (Bimët endemike në florën e Alpeve Shqiptare). Kërkime ASHAK, 9: 79-87.

Millaku, F. \& Elezaj, I. 2015: Tulipa luanica (Liliaceae), a new species from southern Kosovo. Annales Botanici Fennici 52: 315-320.

Millaku, F., Heiselmayer, P., Rexhepi, F., Krasniqi, E., Eichberger, Ch. \& Haziri, A. 2008: Endemic, steno-endemic and relict plants in serpentines of Kosova. Sauteria 16: 149-162.

Millaku, F., Krasniqi, E. \& Rexhepi, F. 2011: The association Stipeto-Convolvuletum compacti ass. nova in Kosovo. Hacquetia 10(2): 137-147.

Millaku, F., Rexhepi, F., Krasniqi, E., Pajazitaj, Q., Mala, Xh. \& Berisha, N. 2013: The Red Data Book of Vascular Flora of Kosovo (Libri i Kuq i Florës Vaskulare të Republikës së Kosovës). MMPH, Prishtinë. 33-163 pp.

Mittermeier, R.A., Robles Gil, P., Hoffman, M., Pilgrim, J., Brooks, T., Mittermeier, C.G., Lamoreux, J. \& da Fonseca, G.A.B. 2004: Hotspots Revisited. CEMEX, Mexico City.

Niketić, M. 1994: Cerastium neoscardicum, a new species of ser. Alpina from Mt. Sar Planina, Serbia. Glasnik Instituta za Botaniku i botaničke bašte Univerziteta u Beogradu 26-27: 63-70.

Peterson, A.D. \& Watson, D.M. 1998: Problems with areal definitions of endemism: the effects of spatial scaling. Diversity and Distributions 4(4): 189-194.

Petrova, A. \& Vladimirov, V. 2010: Balcan endemics in the Bulgarian flora. Phytologia Balcanica 16 (2): 293-311.

Petrova, A. \& Vladimirov, V. (eds.) 2009: Red list of Bulgarian vascular plants. Phytologia Balcanica 15(1): 63-94.

Pimmet, S.L., Russell, G.J., Gittleman, J.L. \& Brooks, T.M., 1995: The future of biodiversity. Science 269: 347-350.

Rexhepi, F. \& Krasniqi, E., 2004: Real condition of stenoendemic species Aristolochia merxmuelleri Greuter et E. Mayer 1985 after NATO bombing in Kosovo war of 1999. Hacquetia 3(1): 93-97.

Rexhepi, F. 1979: Endemic plant community Potentillo-Fumanetum bonapartei Rexhepi 1979, ass. nov. Acta Biologiae et Medicinae Exerimentalis. 4: 41-46.

Rexhepi, F. 1982: Endemics of Ballkan in flora of Kosovarian high mountains (Endemikët e Ballkanit në florën e maleve të larta të Kosovës). Buletini i FSHMN 8: 211-219.

Rexhepi, F. 1982: Endemics of Kosovo (Endemikët e Kosovës). Buletini i Punimeve Shkencore, FSHMN, Prishtinë.

Rexhepi, F. 1994: Flora and vegetation of Kosova, University of Prishtina, Kosovo. 102 pp.

Rexhepi, F. 1997: Genus Crepis, Fam: Asteraceae in flora of Kosovo. (Gjinia Crepis (Shmanga) Fam. Asteraceaee (Compositae) në florën e Kosovës). Bioteknologjia 1: 91-97.

Rexhepi, F. 2000: Endemic plants of Kosovo (Bimët endemike të Kosovës). Faculty of Natural Sciences, University of Prishtina, Prishtina, Kosovo. 25-118 pp.

Shuka, L., Tan, K. \& Krasniqi, E. 2012: Tulipa kosovarica (Liliaceae), a new species of tulip from Kosovo. Phytotaxa 62: 1-9.

Smith, P., Dickie, J., Linington, S., Probert, R. \& Way, M. 2010: Making the case for plant diversity. Seed Science Research 21: 1-4.

Stevanović, V. 1996: Analysis of the Central European and Mediterranean orophytic element on the mountains of the W. and Central Balkan Peninsula, with special reference to endemics. Bocconea 5: 77-97.

Stevanović, V. (ed.) 1999: Red data book of Serbian flora 1 (Crvena knjiga flore Srbije 1) (Iščezli i krajnje ugroženi taksoni). MZSRS. Beograd.

Stevanović, V. 2005: Assessment of biodiversity from internpretation to conservation. Example endemic vascular flora of the Balkan Peninsula (Procena biodiverziteta od interpretacije do konzervacije. Primer endemične vaskularne flore Balkanskog poluostrva). In: Anđelković, M. (ed.): Biodiverzitet na početku novog milenijuma, Zbornik radova sa naučnog skupa. Srpska Akademija Nauka i Umetnosti, Naučni skupovi CXI, Odeljenje hemijskih i bioloških nauka 2: Belgrade: Srpska akademija nauka i umetnosti: 53-73.

Stevanović, V., Tan, K. \& Iatrou, G. 2003: Distribution of the endemic Balkan flora on serpentine. I. Obligate serpentine endemics. Plant Systematics and Evolution 242: 149-170.

Stevanović, V., Tan, K. \& Petrova, A. 2007: Mapping the endemic flora of the Balkans a progress report. Bocconea 21: 131-137.

Tan, K., Stevanović, V. \& Strid, A. 2007: Distribution and centres of diversity for endemic geophytic monocots in the Balkans. Bocconea 21: 139-146.

Tatić, B. \& Krivošej, Z., 1997: Tulipa serbica (Liliaceae), a new species from Serbia. Bocconea 5: 733-736.

Tisdell, C.A. 2014: Human values and biodiversity conservation. The survival of wild species. Edward Eldgar. The University of Queensland, Australia. 34 pp.

The Plant List 2010: Version 1. Published on the Internet: http://www. theplantlist.org/ (accessed 20th of June 2015).

Tomović, G., Niketić, M., Lakušić, D., Ranđelović, V. \& Stevanović, V. 2014: Balkan endemic plants in Central Serbia and Kosovo regions: distribution patterns, ecological characteristics, and centres of diversity. Botanical Journal of the Linnean Society 176: 173-202.

Turrill, WB., 1929: The Plant Life of the Balkan Peninsula. A Phytogeographical Study. Clarendon. Oxford. $91 \mathrm{pp}$.

Tutin, T. G. (eds.), Burges, N. A., Chater, A.O., Edmondson, J.R., Heywood, V.H., Moore, D.M., Valentine, D.H., Walters, S.M. and Webb, D.A. 1964-1980, 1993: Flora Europaea. Vols 1-5 \& Vol. 1 second edition. Cambridge: Cambridge University Press. 208-904 pp.

Volis, S. 2016: How to conserve threatened Chinese plant species with extremely small populations? Plant Diversity 1: 1-11.

Walter, K. S. \& Gillett H. J. (eds.) 1998: 1997 IUCN Red List of Threatened Plants. Compiled by the World Conservation Monitoring Centre. IUCN - The World Conservation Union, Gland, Switzerland and Cambridge, UK. ixiv + 862 pp.

Wilcove, D.S., Rothstein, D., Dubow, J., Phillips, A. \& Losos, E. 1998: Quantifying threats to imperiled species in the United States: assessing the relative importance of habitat destruction, alien species, pollution, over-exploitation, and disease. BioScience, 48: 607-616. 


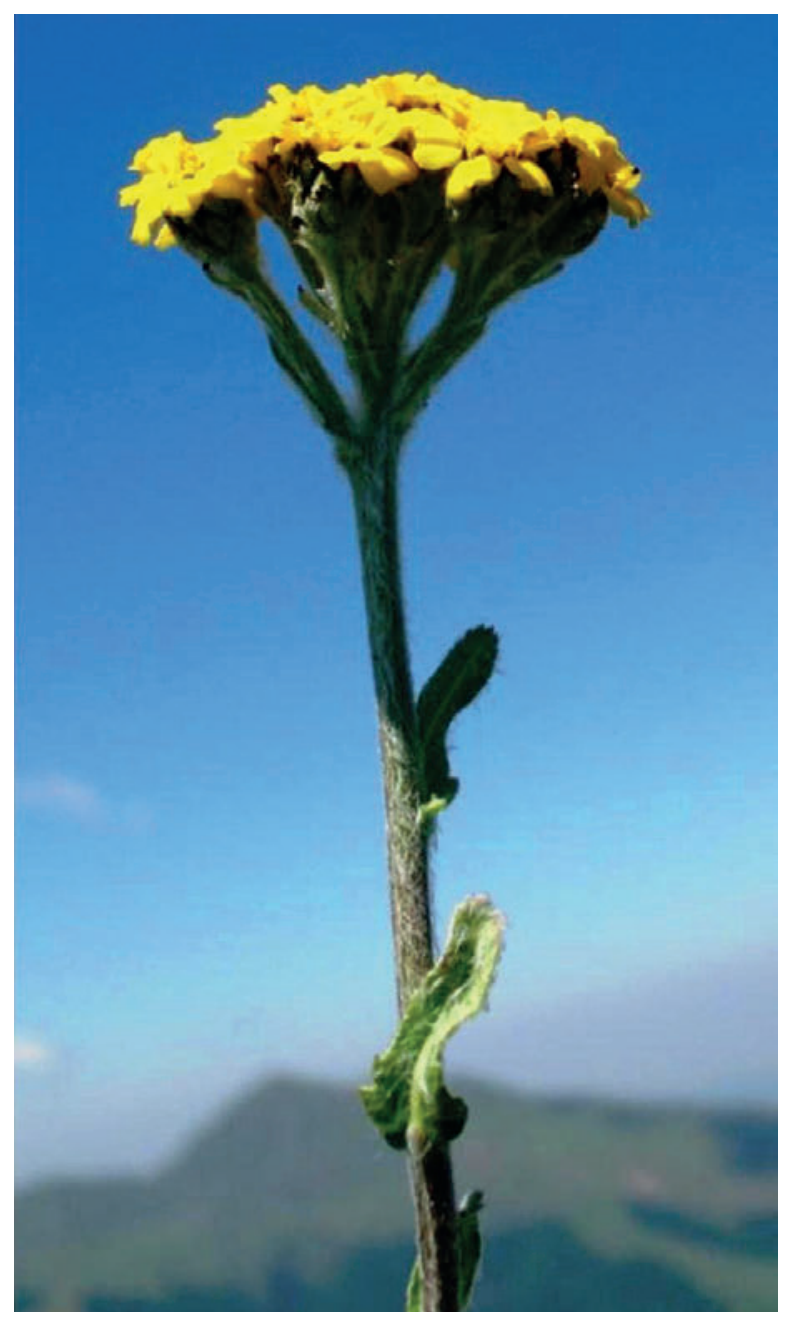

Figure 4 (Slika 4): Achillea alexandri - regis Bornm. \& Rudsky.

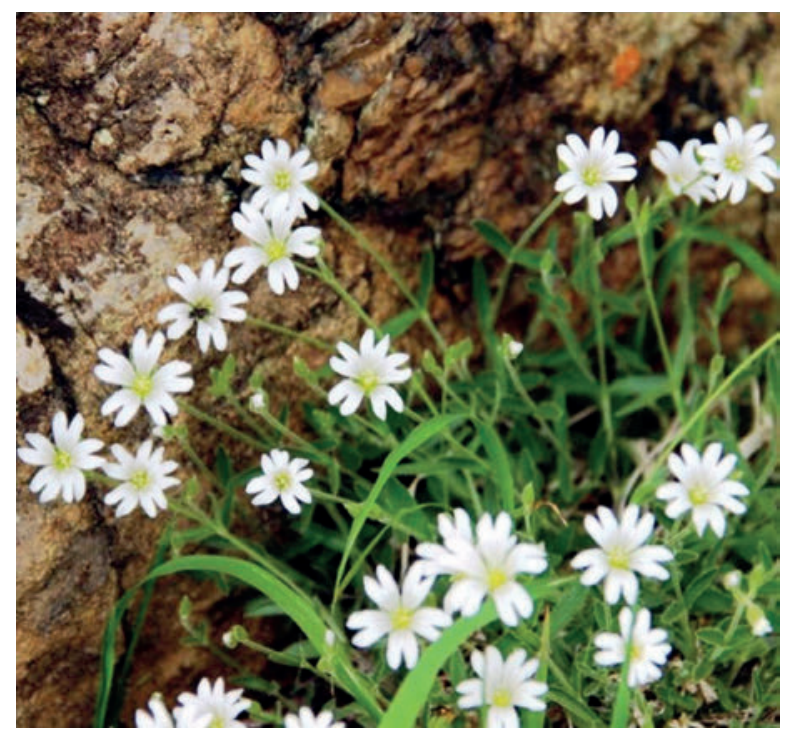

Figure 6 (Slika 5): Cerastium neoscardicum Niketić.

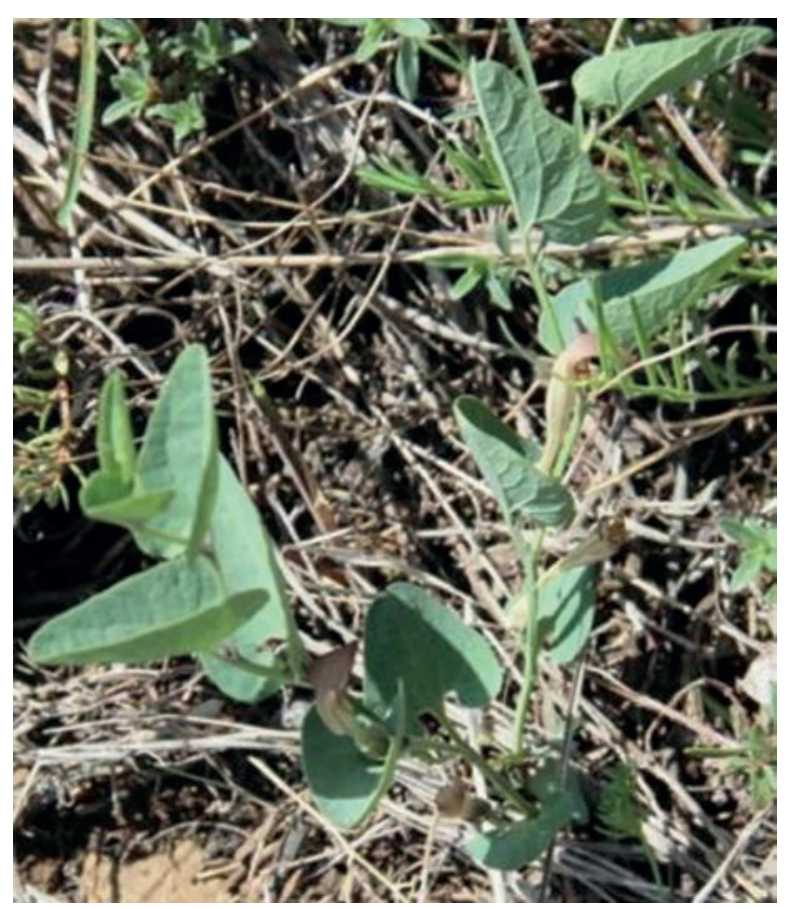

Figure 5 (Slika 5): Aristolochia merxmuelleri Greuter \& E. Mayer.

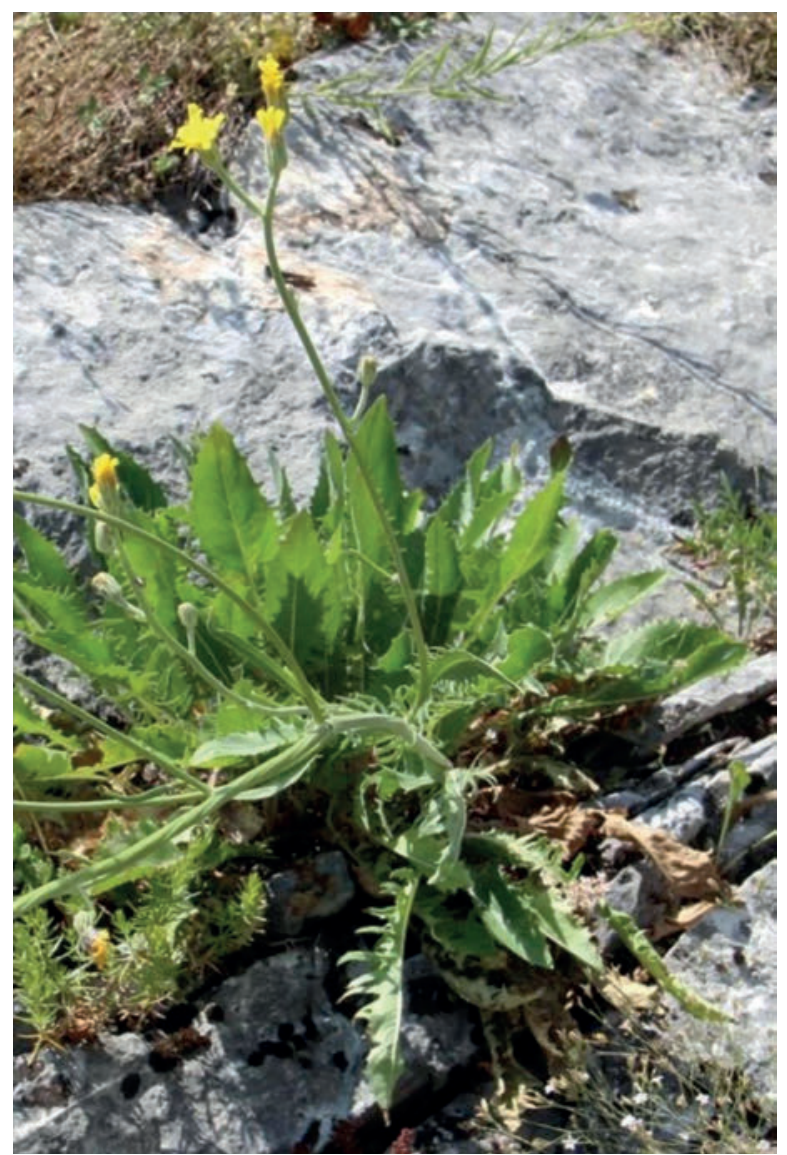

Figure 7 (Slika 7): Crepis bertiscea Jav. 


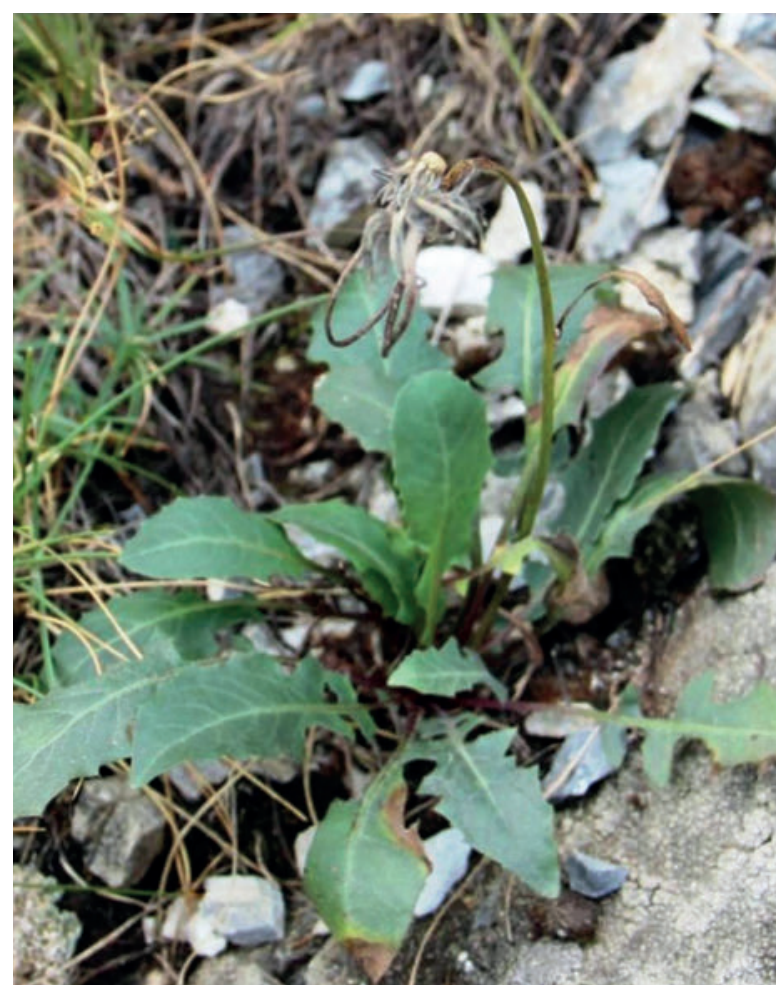

Figure 8 (Slika 8): Crepis macedonica Kitan.

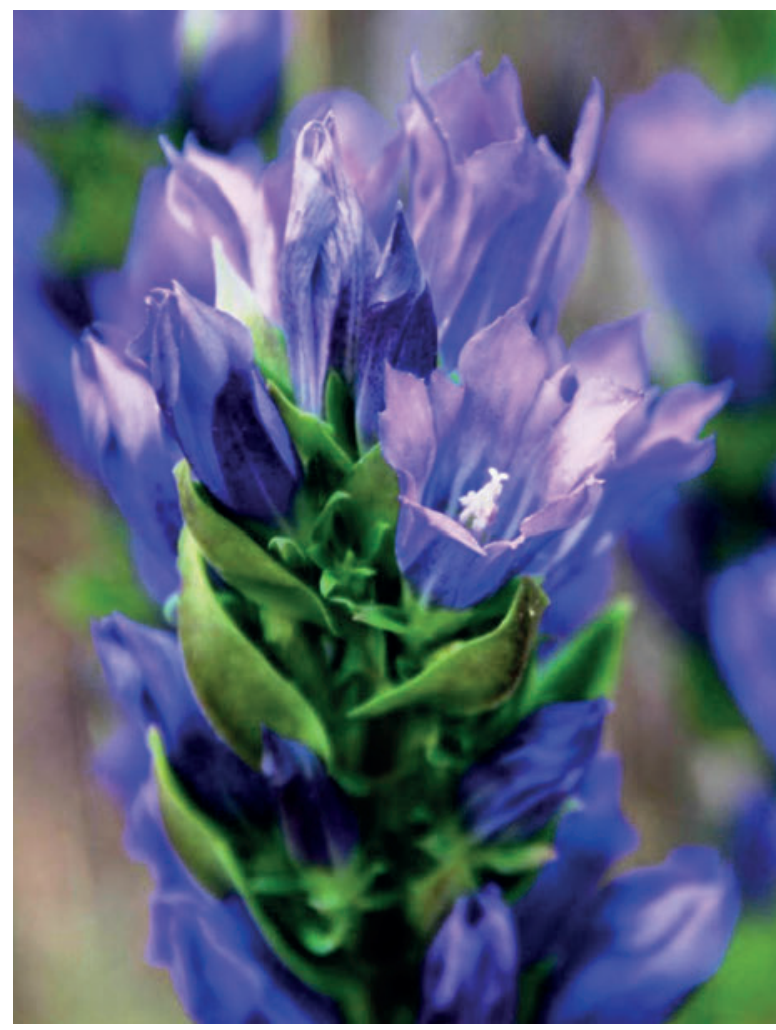

Figure 10 (Slika 10): Gentiana pneumonanthe L. subsp. nopcsae (Jav.) T. Wraber.

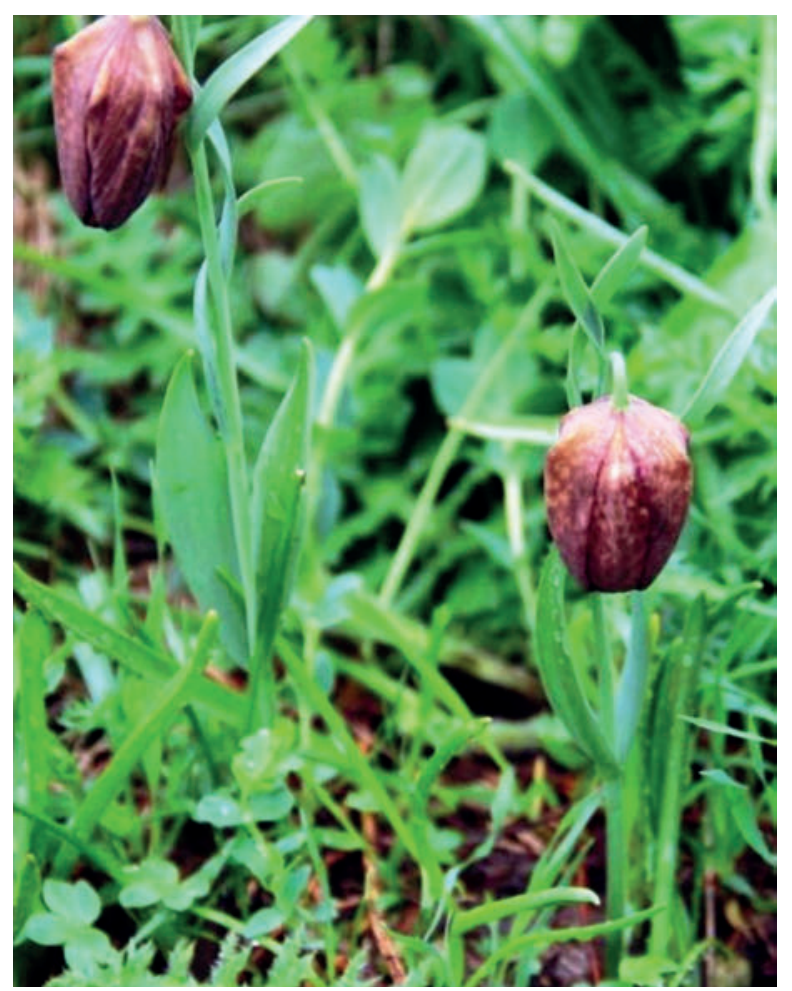

Figure 9 (Slika 9): Fritillaria macedonica Bornm.

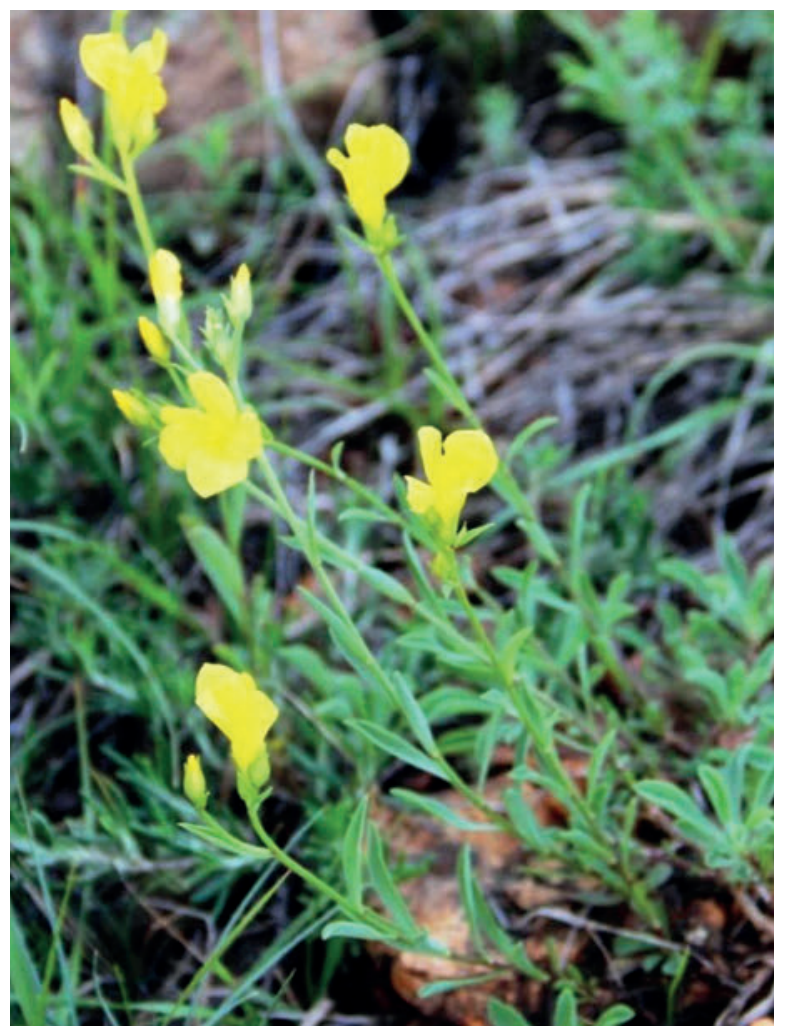

Figure 11 (Slika 11): Linum elegans Spruner ex Boiss. 


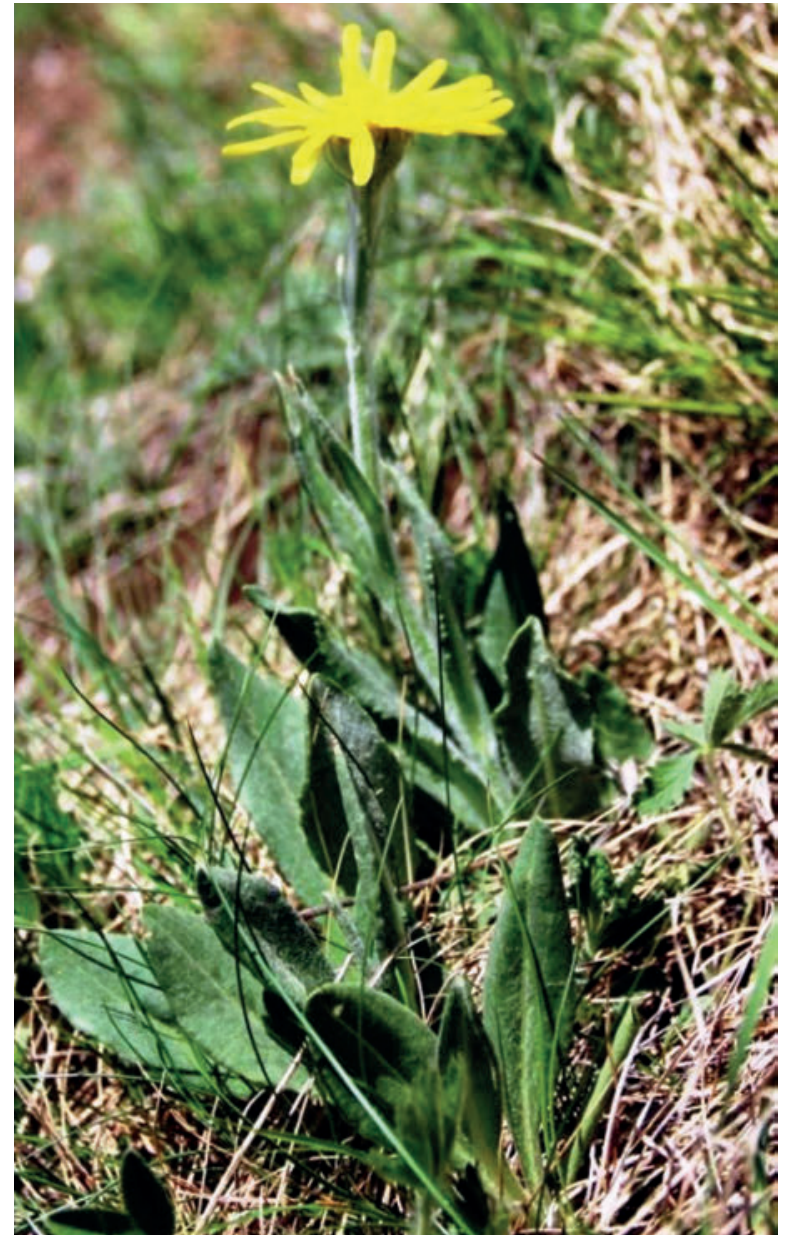

Figure 12 (Slika 12): Senecio scopolii Hoppe \& Hornsch.

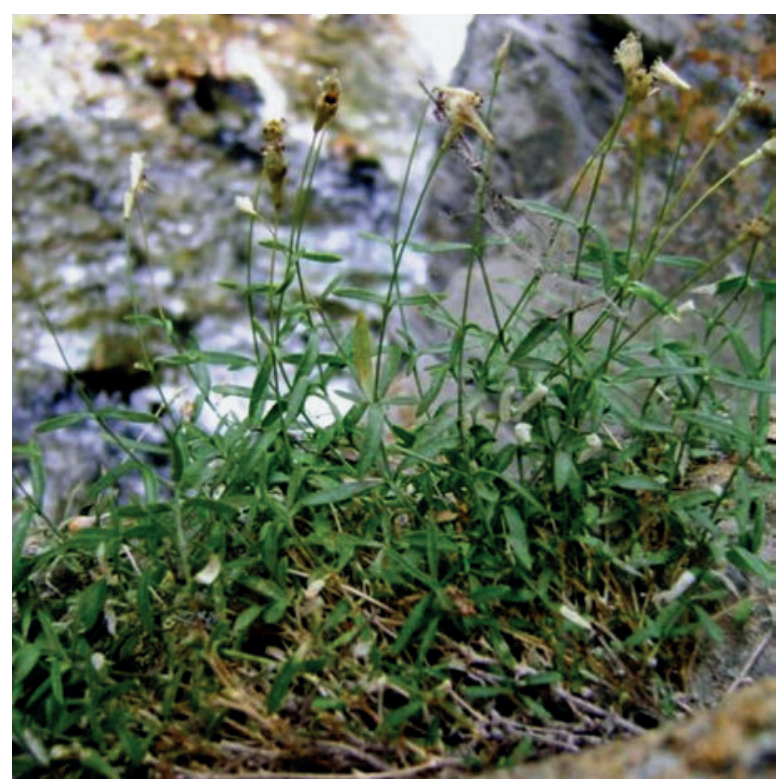

Figure 14 (Slika 14): Silene pusilla subsp. candavica (H. Neumayer) Greuter \& Burdet

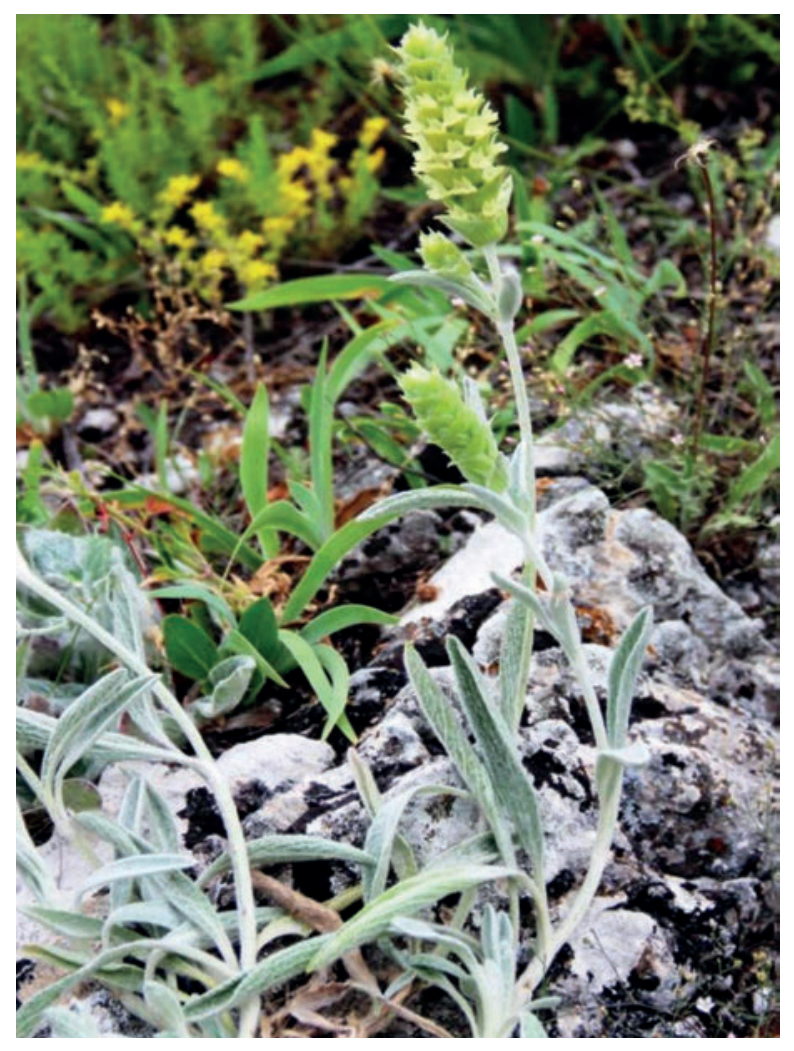

Figure 13 (Slika 13):. Sideritis scardica Griseb.

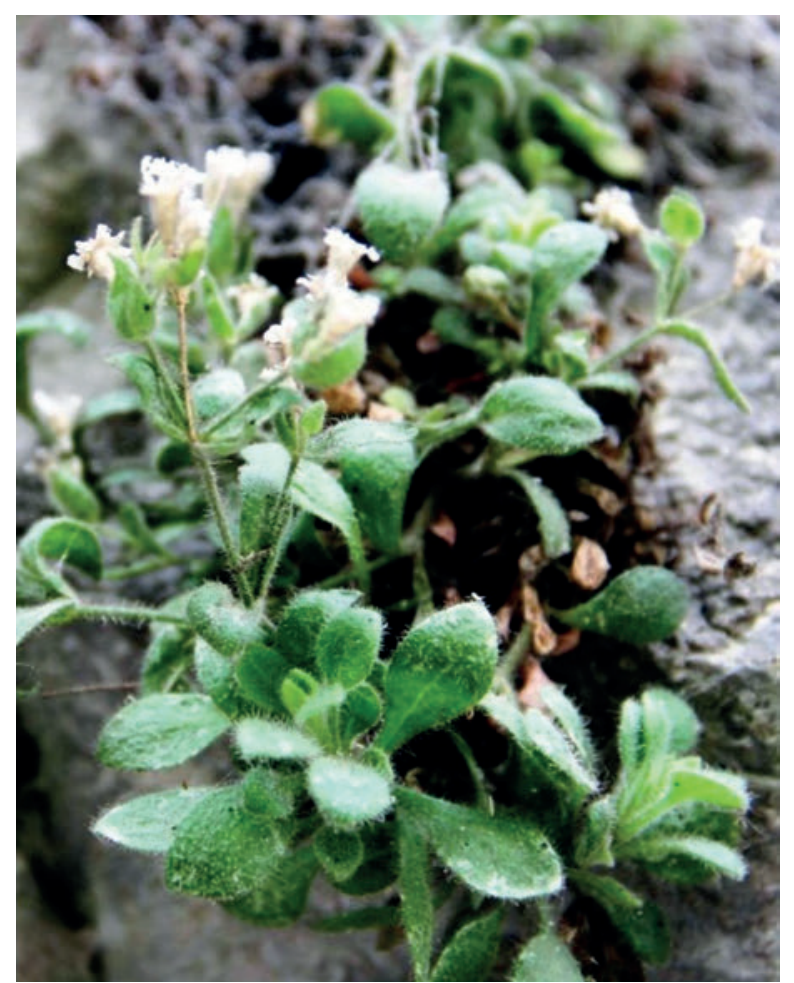

Figure 15 (Slika 15): Silene retzdorffiana subsp. nikolicii 


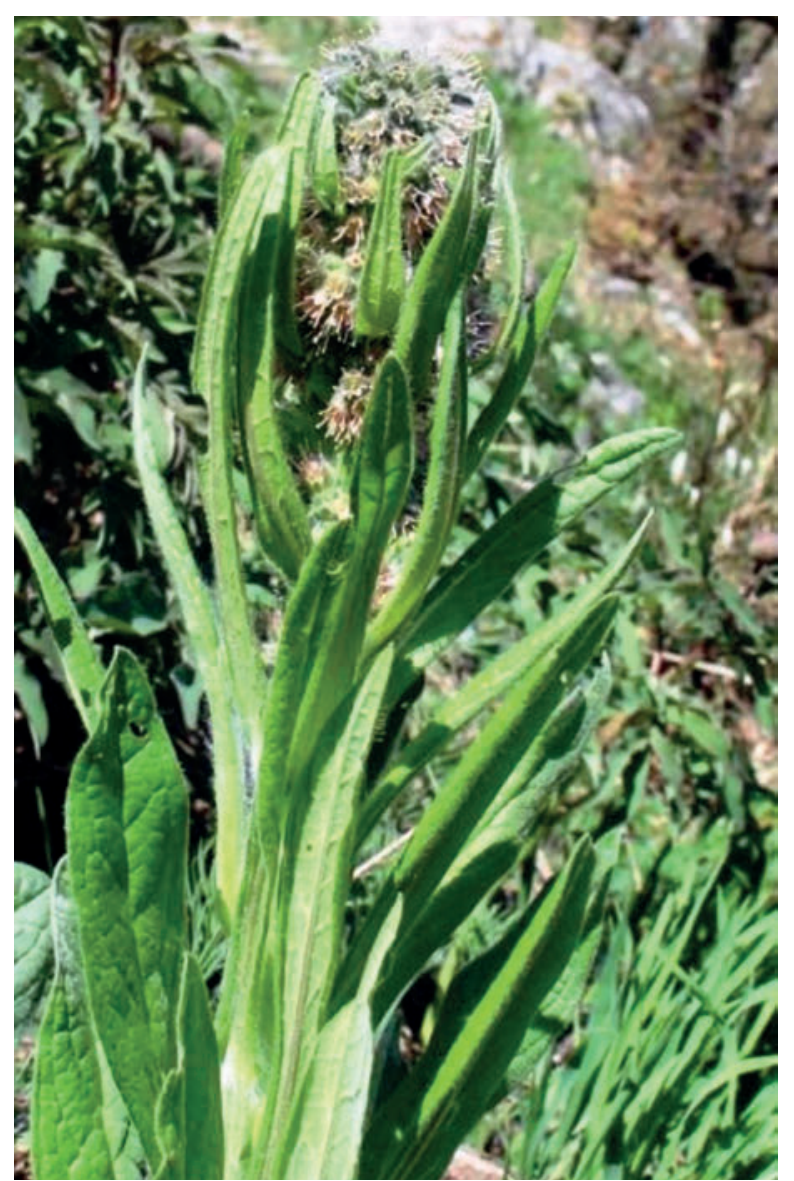

Figure 16 (Slika 16): Solenanthus krasniqii Wraber.

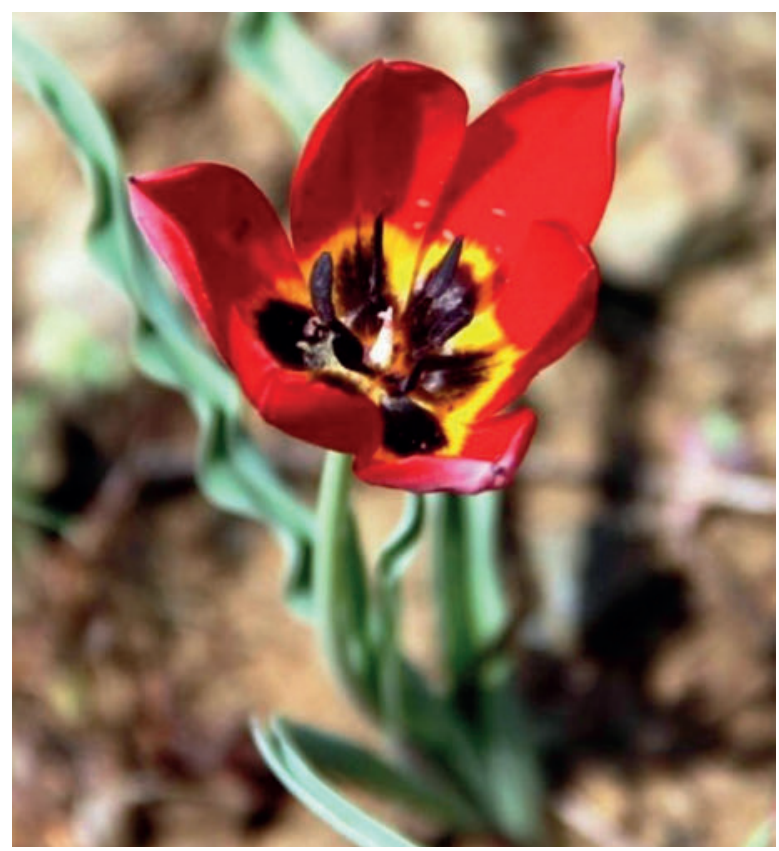

Figure 18 (Slika 18): Tulipa gesneriana L.

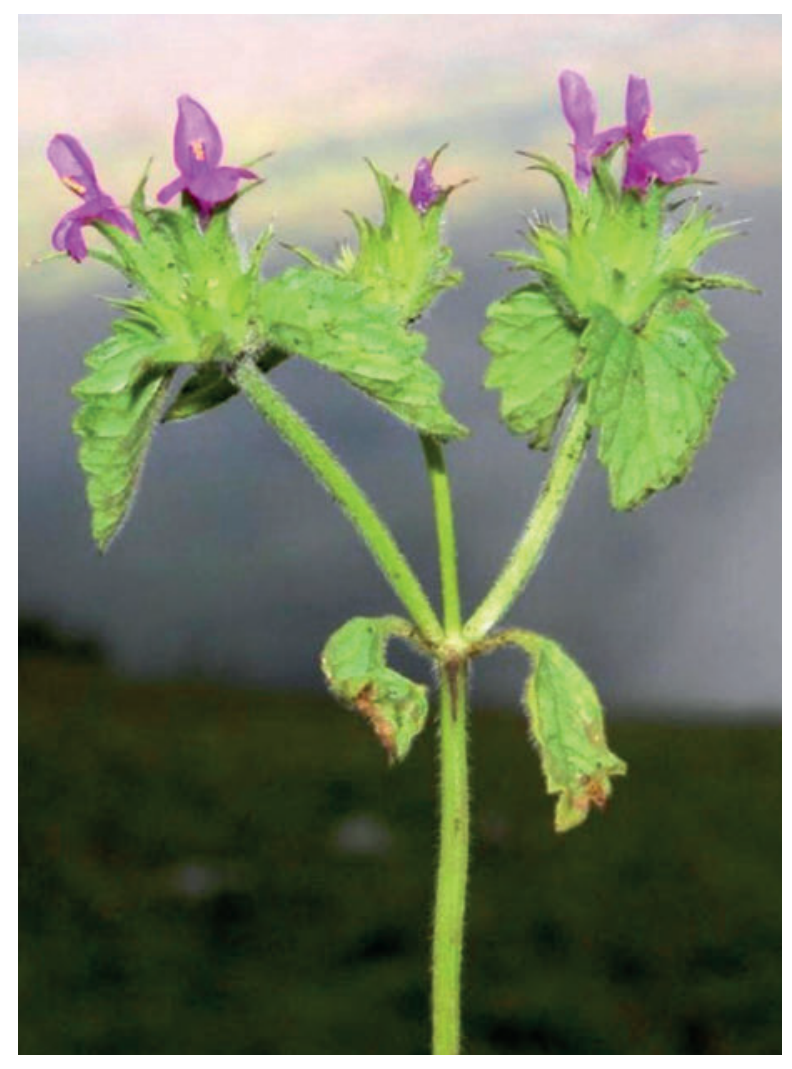

Figure 17 (Slika 17): Stachys serbica Pančić. 